\title{
Effects of Barley Straw and Plastic Fibers on Pozzolan Cement Concrete Properties
}

\author{
Manal O. Suliman \\ Department of Civil Engineering, College of Engineering, Jaresh University, Jaresh, Jordan
}

\begin{abstract}
In the past few decades, some researches have been devoted to use of plastic fibers and other waste materials as additive materials in concrete in order to improve the tensile and compressive strength as well as ductile properties of concrete. Due to these effects this experimental work was undertaken aiming to investigate the behavior of Plastic fibers concrete and barley straw fibers concrete by using readily available local materials. To accomplish the objective, experiments were conducted on plastic fibers concrete and barley straw fibers concrete. The principal variable of the testing program is the amount (percent by weight) of plastic fibers and barley straw fibers which used as replacement of fine aggregate by the following ratio at $(0.1 \%, 0.5 \%, 1 \%$, and $2 \%)$ by weight respectively. Specimens were prepared and tested under standard specification for slump, and compressive strength. The result of the study indicated that the fresh concrete was good enough workable up to $0.5 \%$ replacement of plastic fibers. On the other hand the present of barley straw fibers results in decreasing the workability for all replacement ratios. The addition of plastic fibers to concrete mix results in improvement of the compressive strength for the concrete mixture up to ratio (1\% or less) of plastic fibers. But adding barley straw fibers in concrete mix has a significant effect on decreasing the compressive strength of concrete.
\end{abstract}

Keywords: Barley straw fibers, Plastic fibers, Concrete, Compressive strength, Properties.

\section{INTRODUCTION}

The conventional steel reinforcement concrete makes the reinforced concrete structure heavy and due to water or moisture diffusion through micro cracks developed, steel starts corroding leading to failure of concrete. Moreover, although steel reinforced bars provide strength to the concrete members, they however do not increase the inherent tensile strength concrete itself. They also falls short of desirable properties like toughness, ductility, controlling cracking and energy absorption property because the reinforcement component in reinforced cement concrete is present in certain pockets of the cross section of the structural member. Therefore it is essential to distribute the reinforcement uniformly throughout the cross section by adding short fibers of small diameter that are metallic or nonmetallic to the constituents of the concrete mix. Fibers in the cement based matrix acts as cracks arrester, which confines the growth of flaws in the matrix, preventing these from enlarging under load, into cracks, which eventually cause severe failure. Restriction of propagation of cracks originating from internal flaws can result in improvements in static and dynamic properties of concrete.

Abhishek Jandiyal et al (2016) [1] provide a brief overview on using of plastic fibers made from waste pet bottles in concrete and indicated what aspects of conventional concrete were modified.

Recent literature [Wang and Han (2018)[2], Farooqi and Ali (2016)[3], Cai et al. (2017)[4], Akhras and Afoul (2001)[5], Bouasker et al. (2014)[6], Chen et al. (2017)[7], Munshi et al. (2013)[8], Belhadj et al. (2016)[9], Xie et al. (2016)[10] ] have shown that agricultural waste such as rice and wheat straw can be used in the concrete mix. Studies made by these researchers were conducted on the effect of these natural fibers on the mechanical and physical behavior of concrete, and the results show that the composite achieved considerable strength and toughness.

This study aim to expand the knowledge of aggregate substitutes by investigate the viability of locally available waste materials to form an adaptation of conventional concrete which referred as Green Concrete. The two materials investigated in this study were plastic materials from soft drinks bottles waste and natural barley straw; these materials were used to partially replace fine aggregate and were selected because it is a lighter material than the aggregate it replaces and hence this may result in lighter concrete mixes. If strength is not compromised the use of these materials can be of benefit in terms of reducing the permanent load on a structure.

\section{MATERIALS AND MIX DESIGN METHODOLOGY}

The experimental program was planned to investigate the effect of using barley straw fiber and plastic fiber on the fresh and mechanical properties of concrete, a reference plain concrete mixture was used to compare the results. 


\subsection{Materials Used}

The material details are as follows:

1. Cement: locally available Portland-Pozzolan Cement conforms to Jordanian standard specifications 1-30 / 2016 and European standard EN-197-1/2011 was use throughout the testing.

2. Fine Aggregate: locally available fine aggregate pass from $4.75 \mathrm{~mm}$ sieve locally called Sweileh sand was used.

3. Coarse Aggregate: Coarse aggregate used was $20 \mathrm{~mm}$ and less size with specific gravity 2.80 .

4. Plastic Fibers: The breadth of plastic fibers used in this study is $2 \mathrm{~mm}$ and the length is $40 \pm 2 \mathrm{~mm}$. The plastic fibers were manually cut from soft drinks bottles.

5. Barley Straw Fibers: Barley straw is an agricultural by-product and is the part of cereal stems rejected during the harvest. Locally barley straw was used, which were broken into the length of $40 \pm 2 \mathrm{~mm}$ after naturally air-drying.

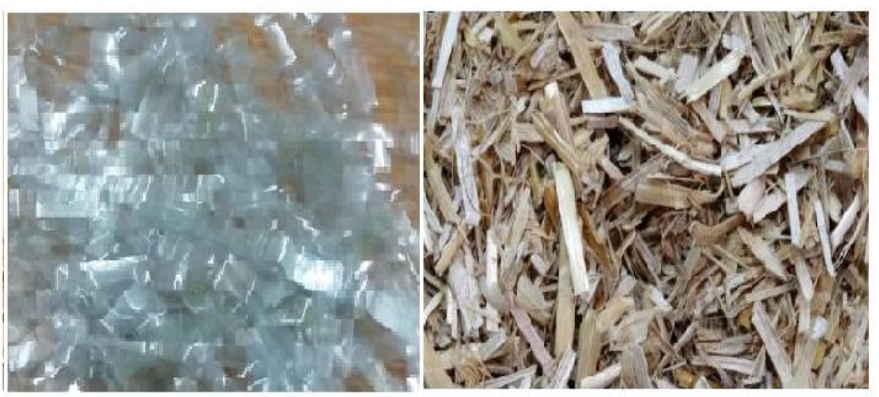

Figure 1: Plastic Fibers and Barley Straw Materials

\subsection{Mix Design Methodology}

In the present study, Concrete mix of M25 grade was designed, and prepared on the basic of guidelines of ACI 211.1, and it was used throughout this investigation. Nine sets of concrete mix samples were prepared with different percentage of replacement of fine aggregate by $0 \%, 0.1 \%$, $0.5 \%, 1 \%$, and $5 \%$, of plastic fibers and barley straw fibers as show in table (1). Steel cube molds of sizes $150 * 150 * 150 \mathrm{~mm}^{3}$ as show in figure 2, were used and three number of such cubes from each concrete mix were tested after 14 and 28 days of curing.

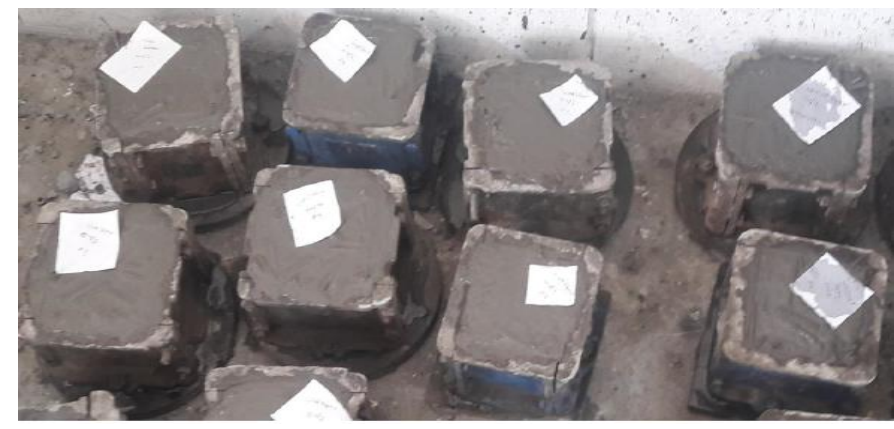

Figure 2: Casting of Cubes

\section{TEST RESULTS AND ANALYSIS}

\subsection{Workability}

The plain concrete (control mixes) were designed to give a slump of $25-75 \mathrm{~mm}$. The slump tests were performed on the fresh concrete for each mix and the results are presented in Table 2.The test results showed that the slump of concrete increase as the percentage of plastic fibers increased up to $0.5 \%$ replacement . On the other hand, the slump of concrete decreased as the barley straw increased, because barley straw has high tendency of water absorption.

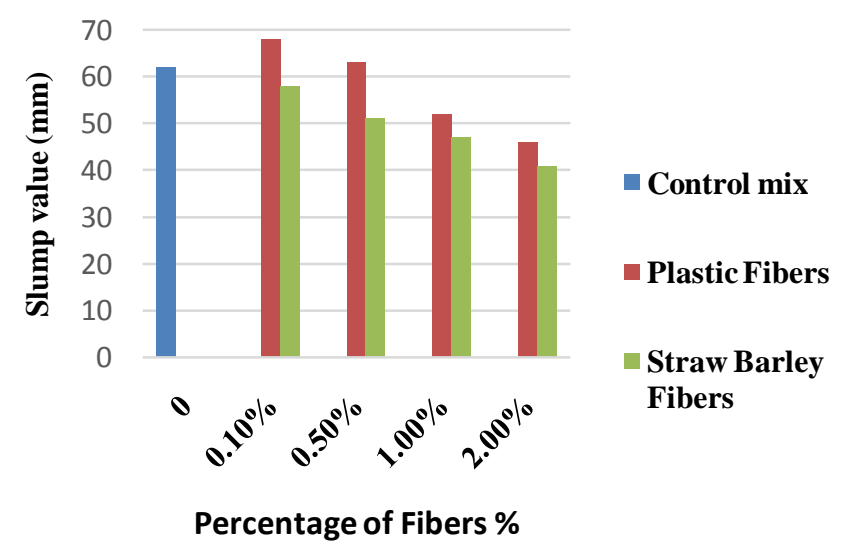

Figure 3: Comparison of Slump Test Results of Plastic Fibers and Barley Straw Fibers Concrete Mixes

Table 1: Mix Proportions for Wet Concrete Mix and Percentage of Plastic Fibers and Barley Straw Fiber for $1.0 \mathrm{~m} 3$ of Concrete

\begin{tabular}{|l|c|c|c|c|c|c|}
\hline \multicolumn{1}{|c|}{ Mix ID } & $\begin{array}{c}\text { Water } \\
\left(\mathrm{Kg} / \mathrm{m}^{3}\right)\end{array}$ & $\begin{array}{c}\text { Cement } \\
\left(\mathrm{Kg} / \mathrm{m}^{3}\right)\end{array}$ & $\begin{array}{c}\text { Coarse } \\
\text { Aggregate } \\
\left(\mathrm{Kg} / \mathrm{m}^{3}\right)\end{array}$ & $\begin{array}{c}\text { Fine } \\
\text { Aggregate } \\
\left(\mathrm{Kg} / \mathrm{m}^{3}\right)\end{array}$ & $\begin{array}{c}\text { Plastic } \\
\text { Fibers } \\
\left(\mathrm{Kg} / \mathrm{m}^{3}\right)\end{array}$ & $\begin{array}{c}\text { barley straw } \\
\text { fibers }\left(\mathrm{Kg} / \mathrm{m}^{3}\right. \\
)\end{array}$ \\
\hline Mix 1 - control mix & 180 & 360 & 1024 & 791 & 0 & 0 \\
\hline $\begin{array}{l}\text { Mix 2 -Adding 0.1 \% of } \\
\text { Plastic Fibers }\end{array}$ & 180 & 360 & 1024 & 790.2 & 0.8 & 0 \\
\hline $\begin{array}{l}\text { Mix 3 - Adding 0.5\% of } \\
\text { Plastic Fibers }\end{array}$ & 180 & 360 & 1024 & 787.045 & 3.955 & 0 \\
\hline
\end{tabular}


ISSN (online): 2581-3048

Volume 4, Issue 9, pp 14-18, September-2020 https://doi.org/10.47001/IRJIET/2020.409003

\begin{tabular}{|l|c|c|c|c|c|c|}
\hline $\begin{array}{l}\text { Mix 4- Adding 1 \% of } \\
\text { Plastic Fiber }\end{array}$ & 180 & 360 & 1024 & 783.03 & 7.91 \\
\hline $\begin{array}{l}\text { Mix 5- Adding 2\% of } \\
\text { Plastic Fibers }\end{array}$ & 180 & 360 & 1024 & 775.18 & 15.82 & 0 \\
\hline $\begin{array}{l}\text { Mix 6 -Adding 0.1 \% of } \\
\text { Barley Straw Fibers }\end{array}$ & 180 & 360 & 1024 & 790.2 & 0 & 0.8 \\
\hline $\begin{array}{l}\text { Mix 7- Adding 0.5 \% of } \\
\text { Barley Straw Fibers }\end{array}$ & 180 & 360 & 1024 & 787.045 & 0 \\
\hline $\begin{array}{l}\text { Mix 8 -Adding 1 \% of } \\
\text { Barley Straw Fibers }\end{array}$ & 180 & 360 & 1024 & 783.03 & 0 & 7.91 \\
\hline $\begin{array}{l}\text { Mix 9-Adding 2 \% of } \\
\text { Barley Straw Fibers }\end{array}$ & 180 & 360 & 1024 & 775.18 & 0 & 15.82 \\
\hline
\end{tabular}

Table 2: Results of slump values of Plastic Fibers and Barley Straw Fibers Concrete Mixes

\begin{tabular}{|l|c|c|}
\hline \multicolumn{1}{|c|}{ Mix ID } & Slump Value $(\mathrm{mm})$ & \% Changes in Slump Value \\
\hline Mix 1 -Control Mix & 62 & 0 \\
\hline Mix 2 -Adding 0.1 \% of Plastic Fibers & 68 & +9.6 \\
\hline Mix 3 - Adding 0.5 \% of Plastic Fibers & 63 & +1.6 \\
\hline Mix 4- Adding 1 \% of Plastic Fiber & 52 & -16.1 \\
\hline Mix 5- Adding 2 \% of Plastic Fibers & 46 & -25.8 \\
\hline Mix 6 -Adding 0.1 \% of Barley Straw Fibers & 58 & -6.4 \\
\hline Mix 7- Adding 0.5 \% of Barley Straw Fibers & 51 & -17.7 \\
\hline Mix 8 -Adding 1 \% of Barley Straw Fibers & 47 & -24.2 \\
\hline Mix 9 -Adding2 \% of Barley Straw Fibers & 41 & -33.8 \\
\hline
\end{tabular}

*(+) Shows the increase in values and (-) Shows the decrease in values

\subsection{Compressive Strength}

The influence of replacing the fine aggregate by plastic fibers and barley straw fibers on the compressive strength of Pozlan an cement concrete are illustrated in table 3.

Table 3: Compressive Strength of Concrete Specimens with Plastic Fibers and Barley Straw Fibers

\begin{tabular}{|c|c|c|c|c|}
\hline $\begin{array}{c}\text { Type of } \\
\text { Added } \\
\text { Materials }\end{array}$ & $\begin{array}{c}\text { Added } \\
\text { Materials Ratio } \\
(\%)\end{array}$ & $\begin{array}{c}\text { Average of } \\
\text { Compressive } \\
\text { Strength at 14 days } \\
(\mathrm{MPa})\end{array}$ & $\begin{array}{c}\text { Average of } \\
\text { Compressive Strength } \\
\text { at 28 days (MPa) }\end{array}$ & $\begin{array}{c}\text { \% Changes in } \\
\text { Average Compressive } \\
\text { Strength at 28 days }\end{array}$ \\
\hline \multirow{5}{*}{ Plastic Fibers } & 0 & 20.1 & 24.6 & 0 \\
\cline { 2 - 5 } & 0.1 & 16.2 & 24.8 & +0.8 \\
\cline { 2 - 5 } & 0.5 & 16.44 & 26.88 & +17.4 \\
\hline \multirow{5}{*}{$\begin{array}{c}\text { Barley Straw } \\
\text { Fibers }\end{array}$} & 1 & 21.03 & 28.88 & +10.6 \\
\cline { 2 - 5 } & 0.1 & 21.4 & 24.6 & -41.3 \\
\cline { 2 - 5 } & 0.5 & 12.58 & 14.45 & -45 \\
\cline { 2 - 5 } & 1 & 12.2 & 13.54 & -53.5 \\
\hline
\end{tabular}

*(+) Shows the increase in values and (-) Shows the decrease in values 
From table 3, adding plastic fibers up to ratio $1 \%$ result in gradually increase of compressive strength, but when adding of $2 \%$ plastic fiber the compressive strength of concrete started decreases. From the visual inspection, it was noticed that the barley straws pull out occurred due to the weak bonding between the straw and matrix.

As illustrate in figures 3 and 4 . In this study adding plastic fiber up to $1 \%$ led to gradual increase of compressive strength up to $17 \%$ from control concrete mix.

Most authors reported a gradual decrease in compressive strength with increasing straw percentages. In this study high reduction of compressive strength were recorded by increasing barley straw percentage in concrete. Adding 2\% of straw in concrete mixture gives about $62 \%$ lower compressive strength when compared with control concrete mix.

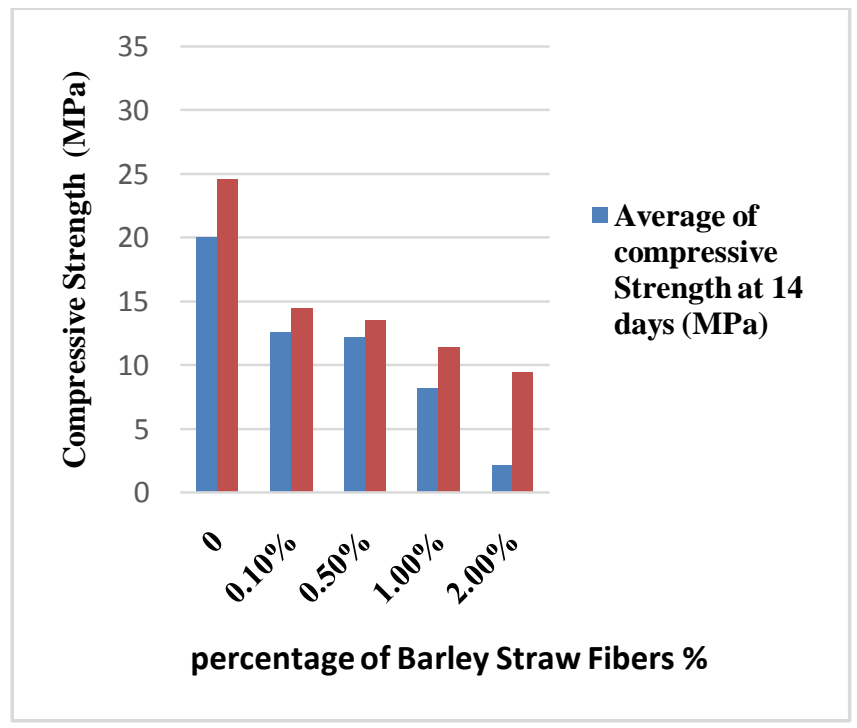

Figure 4: Compressive Strength Results of Plastic Fibers Concrete at 14 and 28 days

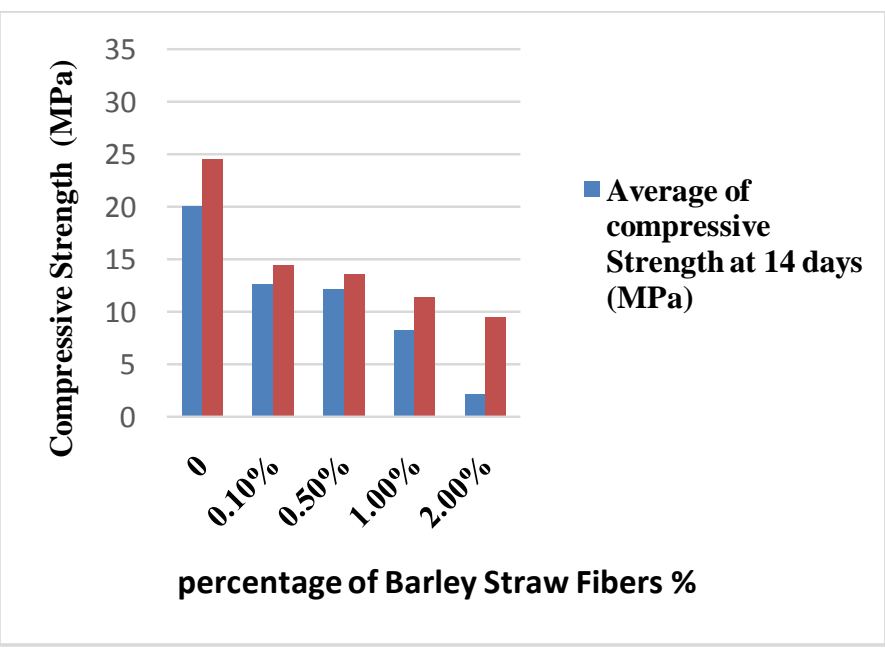

Figure 5: Compressive Strength Results of Barley Straw Fibers Concrete at 14 and 28 days

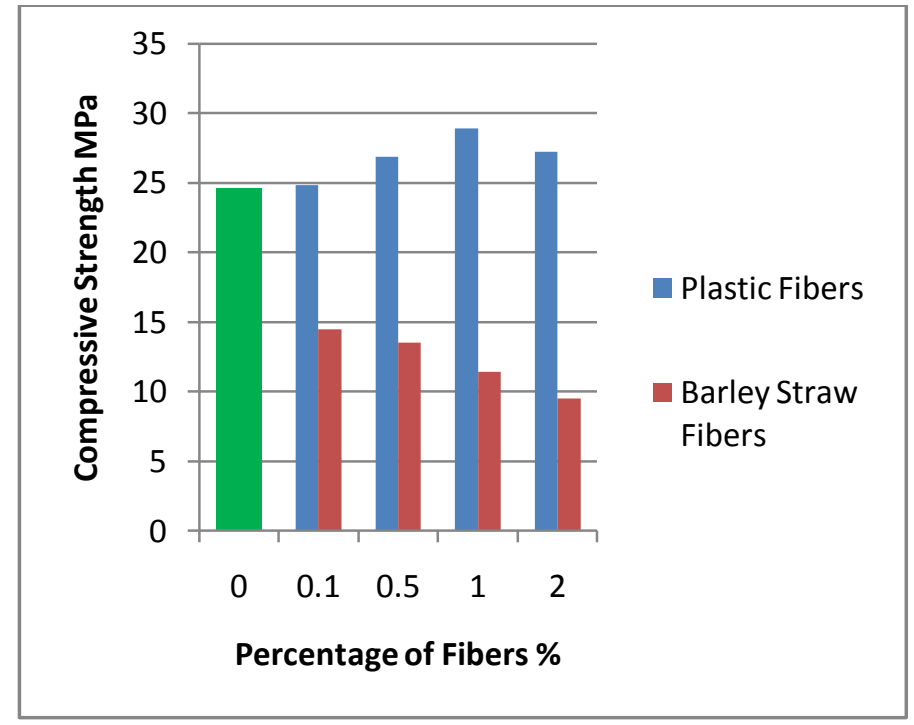

Figure 6: Comparison of Compressive Strength Results of Plastic Fibers and Barley Straw Fibers Concrete at 28 days

This is true regardless of w/c and sample age. The higher the amount of straw in concrete, gives the lower the compressive strength. In this study adding straw $1 \%$ in concrete result in high reduction of compressive strength up to $53 \%$, and, the reduction of compressive strength reached up to $62 \%$ by adding barley straw ratio to $2 \%$ at 28 days.

\section{CONCLUSION}

The conclusion of this study revealed the following remarkable points:

1. The addition of plastic fibers and barley straw fibers strongly affected the workability of the fresh concrete that as the plastic fibers content increased, the workability is increased on the other hand as the barley straw fibers increased the workability is decreased.

2. The improvement of the compressive strength for the mixtures contains plastic fibers up to ratio $(1 \%$ or less) is due to the ability of the mechanical blocking action of the fiber, whereas the decreasing in compressive strength of other mixture containing plastic fibers more than $2 \%$ may be attributed to the decrease in adhesive strength between the surface of plastic fibers and the cement paste.

3. The addition of plastic fibers more than $2 \%$ increases the number of air voids in the matrix, which leads to lower compressive strength. Also, the untreated surfaces of plastic fibers do not bond well with the cement matrix. Thus, a weaker interfacial zone is formed between the binders and plastic fibers, which ultimately lead to the lower strength of the concrete. 
ISSN (online): 2581-3048

4. The addition of barley straw fibers in concrete reduces the concrete compressive strength.

5. Pull out of the straws is also common mode of failure of barley straw concrete due to the lowest bond strength.

6. Further laboratory studies are needed to study the real behavior and understand the factors that affect the concrete mixed with plastic fibers and barley straw fibers materials.

\section{REFERENCES}

[1] Abhishek Jandiyal; Sandeep Salhotra; Raju Sharma; UmerNazir. "A review on using fibers made from waste pet bottles in concrete", International Journal of Civil Engineering and Technology (IJCIET), Volume 7, Issue 4, pp. 553-564, August 2016.

[2] Wang, G., \& Han, Y. "Research on the performance of straw fiber concrete", Materials Science and Engineering, 394(3), pp. 1-4, 2018.

[3] Farooqila, M. U., \& Ali1b, M., "Compressive behavior of wheat straw reinforced concrete for pavement applications", Fourth International Conference on Sustainable Construction Materials and Technologies. Las Vegas, USA, PP.7-11, 2016.

[4] Cai, J. W., Li, Z., Yan, S. J., \& Li, J., "Effect of straw fiber content on properties of cement-based composite", DEStech Transactions on Engineering and Technology Research, 2017.

[5] Al-Akhras, N. M., \& Abu-Alfoul, B. A., "Effect of wheat straw ash on mechanical properties of autoclaved mortar", Cement and Concrete Research, 32(6), PP. 859-863, 2002.

[6] Bouasker, M., Belayachi, N., Hoxha, D., \& AlMukhtar, M., "Physical characterization of natural straw fibers as aggregates for construction materials applications", Materials, 7(4), PP. 3034-3048, 2014.

[7] Chen, J., Elbashiry, E. M. A., Yu, T., Ren, Y., Guo, Z., \& Liu, S., "Research progress of wheat straw and rice straw cement-based building materials in china",
Magazine of Concrete Research, 70(2), PP.84-95, 2017.

[8] Bederina M. Belhadj, B. Ammari M. S., Gouilleux A., Makhloufi Z., Montrelay N., and, Queneudec M., "Improvement of the properties of a sand concrete containing barley straws-treatment of the barley straws", Construction and Building Materials, 115, PP.464-477, 2016.

[9] Xie, X., Gou, G., Wei, X., Zhou, Z., Jiang, M., Xu, X., \& Hui, D. ,"Influence of pretreatment of rice straw on hydration of straw fiber filled cement based composites", Construction and Building Materials, 113, PP. 449-455, 2016.

[10] ASTM C109, "Standard Test Method for Compressive Strength of cube Concrete Specimens", American Society for Testing and Materials Standard Practice C109, Philadelphia, Pennsylvania, (2004).

[11] Agopyan, V., Savastanojr, H., John, V. and Cincotto, M., "Developments on Vegetable Fibre-Cement based Materials in Sau Paulo, Brazil: An Overview", Cement Concrete Compos, 27(5), pp.527-536, 2005.

[12] Salahaldein Alsadey "Effect of Polypropylene Fiber Reinforced on Properties of Concrete", Journal of Advance Research in Mechanical and Civil Engineering, Volume-3, Issue-4, pp.18-22, 2016.

[13] Prahallada, MC. "Effect of Different Aspect ratio of Waste Plastic Fibres on the Properties of Fibre Reinforced Concrete -An Experimental Investigation", International Journal of Advanced Research in IT and ngineering, Vol.2, No.2, pp 1-12, 2013.

\section{AUTHOR'S BIOGRAPHY}

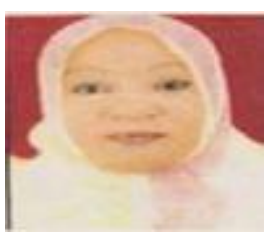

Dr. Manal Osman Suliman,

Assistant Professor at department of civil engineering, College of Engineering, Jerash University, Jerash, Jordan

\section{Citation of this Article:}

Manal O. Suliman, "Effects of Barley Straw and Plastic Fibers on Pozzolan Cement Concrete Properties" Published in International Research Journal of Innovations in Engineering and Technology - IRJIET, Volume 4, Issue 9, pp 14-18, September 2020. https://doi.org/10.47001/IRJIET/2020.409003 